\title{
SUPPORT PENDDIDIKAN PERAWAT DENGAN TEKNOLOGI CLICKERS PUJI ASTUTI \\ FIK-UNUSA
}

(Jl. Smea no 57 Surabaya)

Email:pujidaniar@yahoo.com

\begin{abstract}
Supporting Nursing Education by using Clickers Technology" The educational process in nursing recently shows a rapid development, a variety of learning methods are applied to achieve the learning objectives, and even the use of computer has become a student need. Nursing education now is widely supported by technologies, one of them is Clickers. Clickers is Student Response Systems. The purpose of this article is studying and discussing the literature about Clickers technology and its application analysis in support of education

The result is a lot of research trying to apply the clickers in the classlearning and produce results that Clickers help in understanding the content and bring greater student involvement during lectures, student feel satisfied and the learning outcomes are increased. Clickers is supporting the teaching and learning activities in which these activities need to be developed to have an advanced system. Clickers facilitate the process of teaching, and teacher assessment and report student learning outcomes.
\end{abstract}

\begin{abstract}
ABSTRAK
Proses pendidikan dalam keperawatan dewasa ini menunjukkan arah perkembangan yang pesat, berbagai metode pembelajaran diterapkan untuk mencapai tujuan belajar, bahkan penggunaan computer sudah menjadi kebutuhan setiap siswa. Pendidikan keperawatan saat ini banyak didukung oleh teknologi, salah satunya adalah Clickers. Clickers adalah suatu sistem respon siswa.. Tujuan dalam artikel ini adalah mengkaji dan membahas literature tentang tekhnologi Clickers dan analisis aplikasinya dalam mensupport pendidikan keperawatan

Hasilnya banyak penelitian yang mencoba mengaplikasikan Clickers dalam pembelajaran di kelas dan membuahkan hasil yaitu Clickers membantu dalam pemahaman konten dan membawa keterlibatan siswa yang lebih besar selama kuliah, siswa merasa puas dan hasil belajar meningkat.. Clickers merupakan pendukung dalam kegiatan belajar mengajar dimana kegiatan ini perlu dikembangkan untuk beranjak pada system yang lebih maju. Clickers memudahkan proses pengajaran, memudahkan pengajar dalam penilaian dan pelaporan hasil belajar siswa.
\end{abstract}




\section{PENDAHULUAN}

Pendidikan perawat banyak menggunakan berbagai teknik untuk mencapai tujuannya, mengingat masing masing individu mempunyai gaya belajar yang berbeda - beda maka ada beberapa cara pembelajaran yang bisa dilakukan agar tujuan pembelajaran tercapai. Setiap kali orang belajar, ia selalu berada dalam konteks tertentu, (yaitu kondisi yang melingkupi proses belajarnya), asupan belajar, cara memproses asupan, dan system penyaringan respon. Konteks ini memberi corak kepada proses belajarnya, secara berbeda-beda tergantung kecenderungan yang ada pada orang tersebut. Dalam hal asupan belajar, orang bisa mengindera dari luar, tetapi juga bisa dari dalam. Asupan belajar yang umum dipergunakan orang dalam belajar adalah visual, auditory, dan kinesthetic (Gunarya, 2006). Dalam cara memproses asupan terbagi menurut beberapa type orang. Sementara dari sistem penyaringan respon tiap orang dibedakan menurut perangkat saringan yang digunakan. Berkaitan dengan system pendidikan dapat formal di dalam kampus atau non formal sebagai penunjang dengan berbagai kursus.

Pelaksanaan kursus jarak jauh sering dilakukan untuk menunjang pendidikan perawat, tetapi ada beberapa kendala, secara historis, yaitu sulit untuk meminta keterlibatan siswa, terutama dari lokasi jauh. Kursus ini terutama didukung oleh slide power point dan penggunaan kuis dan studi kasus. Fakultas mencatat bahwa siswa sering tidak hadir, bahkan dengan menggunakan presentasi power point yang sudah ditingkatkan. Kurangnya keterlibatan dan pemahaman tampak jelas pada ujian, siswa menemukan beberapa pertanyaan yang sulit dijawab, bahkan meskipun mereka pikir akrab dengan informasi tersebut.

Penelitian telah menunjukkan bahwa siswa generasi sekarang dalam melakukan pembelajaran memiliki kecenderungan untuk menggunakan literature digital, pengalaman belajar, interaktivitas, dan kedekatan, sehingga penggunaan teknologi yang lebih maju sedang dibawa ke dalam program universitas untuk membantu dalam keterlibatan siswa. Salah satu teknologi tersebut adalah clickers.

Clickers adalah suatu system respon siswa. Penelitian tentang Support teknologi pada pendidikan keperawatan menggunakan Clickers didalam kelas telah diteliti oleh Berry mulai tahun 2005 sampai dengan 2006 yang dipublikasikan tahun 2009.

\section{Tujuan}

Mengkaji dan membahas literature tentang tekhnologi Clickers dan analisis aplikasinya dalam mensupport pendidikan keperawatan

\section{KAJIAN LITERATUR Konsep Perilaku Belajar}

Ada empat aspek utama yang membangun sekaligus membedakan perilaku belajar seseorang dengan orang lainnya, yaitu (1) konteks belajar, (2) asupan belajar, (3) cara memproses asupan dan (4) sistim penyaringan respons. ( Gunarya, 2006)

\section{Konteks Belajar}

Sekurangnya dapat dipilah dalam empat variabel, yaitu

(1) Lingkup Belajar

Lingkup belajar mempunyai dua kutub yaitu 'Field dependent' dan Field independent'. Sebagian orang lebih memilih belajar dalam kondisi 
alamiahnya, pada kehidupan nyata, di lapangan; mereka disebut 'Field dependent'. Sebagian lainnya tidak terlalu mempersoalkan lingkungan, dimana dan dari mana pun mereka bisa belajar, bisa dari kenyataan hidupnya, tetapi bisa juga dari hasil olah orang lain seperti dari komputer, buku, dst. Mereka dikategorikan sebagai 'Field independent' (2) Area belajar

Tempat/ area belajar dengan kutub fleksibel di satu sisi dan kutub terstruktur di sisi lain. Sejumlah orang bisa fleksibel belajar di mana saja, bervariasi tidak harus pada area tertentu. Mereka tergolong dalam kutub 'Flexible environment'. Sedangkan sejumlah lainnya baru bisa belajar, pada area tertentu. Dengan perkataan lain mereka membutuhkan lingkungan yang tertentu, dengan aturan tertentu. Dalam variabel area belajar, mereka termasuk dalam golongan 'Structured environment'

(3) Teman belajar

Sekelompok orang cenderung lebih efektif belajarnya, apabila mereka sendirian, dan mereka digolongkan sebagai orang yang 'independent'. Sementara sebagian orang lain, lebih memilih belajar bersama teman, apakah berpasangan atau dalam kelompok kelompok kecil, karena merasa lebih bisa efektif belajar bersama teman. Mereka tergolong sebagai 'dependent'. Sedangkan kelompok lainnya lagi, mereka bisa belajar baik sendiri maupun bersama teman, dan mereka digolongkan sebagai kelompok yang 'interdependent'

(4) Pemicu Belajar

Sebagian orang bisa atau tidak bisa belajarnya terpengaruh oleh siapa yang memberi pelajaran, artinya tergantung pada kualitas hubungan dirinya dengan orang yang mengajar. Mereka digolongkan dalam kelompok 'Relationship driven', sementara kelompok lainnya yang disebut
'Content driven', semangat belajarnya lebih terpacu oleh isi subyek yang dipelajari, yang mereka anggap penting; mereka tidak terlalu mempersoalkan siapa yang memberikan pembelajaran.

\section{Asupan belajar - input.}

Berkenaan dengan asupan belajar, orang bisa mengindera dari luar, tetapi juga bisa dari dalam. Sesuai dengan jumlah indera kita, maka sekurangnya ada lima type asupan, yaitu visual melalui penglihatan, auditory melalui pendengaran, kinesthetic melalui perabaan gerakan, olfactory melalui penciuman dan gustatory melalui pengecapan. Bahkan ada pula yang menganggap lebih dari kelima asupan diatas, seperti ; vestibular- gerakangerakan otot berulang, magnetic orientasi yang bersifat feromagnetic, ionic - charges atmosfir elektrostatik, geogravimetric - merasakan perbedaan massa, proximal - kedekatan secara fisik, dan sebagainya. Namun demikian, yang umum dipergunakan orang dalam belajar adalah tiga asupan yang pertama, yaitu visual, auditory, dan kinesthetic

\section{Memproses Asupan.}

Dalam memproses asupan belajar, type orang juga berbeda-beda. Setidaknya dapat dipilah kedalam empat tipe, yaitu (1) tipe global, (2) tipe keurutan, (3) tipe konseptual dan (4) tipe kongkrit. Berikut kita bahas satu persatu.

(1) Kelompok global - Contekstual global: Orang-orang yang tergolong dalam kelompok ini, biasanya memproses asupan informasi secara keseluruhan (overview) terlebih dahulu, jadi cenderung gestalt, holistik,dan lateral

(2) Kelompok keurutan - Sequential detailed. Mereka yang tergolong dalam kelompok ini, memproses asupan informasi secara bertahap sesuai urutan, jadi cenderung linier.

(3) Kelompok Konseptual 
Mereka yang tergolong dalam kelompok ini, biasa memproses asupan informasi dari buku, artikel, internet, gagasan, percakapan,dan sebagainya . Mereka lebih senang memproses secara abstrak di pikiran mereka, bermain dengan idea, tetapi tidak begitu suka berbuat, bertindak atau bergerak.

(4) Kelompok Kongkrit

Orang-orang di kelompok ini lebih senang memproses objek yang bisa secara kongkrit mereka indera, raba, lihat dan tangani secara nyata. Pada umumnya mereka lebih menyukai segala sesuatu yang membutuhkan gerak tubuhnya.

\section{Hasil Proses akan melalui saringan respons}

Setelah asupan diproses, diolah akan dihasilkan 'bakal respon'. Bakal respon ini akan melalui suatu saringan/ayakkan respon, barulah menjadi respon. Dengan perkataan lain respon belajar seseorang, selain ditentukan oleh prosesing dari asupan informasi, ditentukan juga oleh saringan atau ayakkan respon yang dianut/dipakai oleh yang bersangkutan. Saringan respon ini berbeda-beda, tergantung dari tipenya. Sekurangnya ada 3 macam perangkat saringan, yaitu (1) Rujukan eksternal/internal, kecenderungan menyepakati menyandingi dan (3) impulsive /reflektif

\section{Teknologi Clickers}

Saat ini siswa memiliki pilihan menggunakan digital literatur, pengalaman belajar, interaktivitas, dan kedekatan (Howe \& Strauss, 2000; Skiba \& Barton, 2006). Penggunaan teknologi yang lebih bagus telah diperkenalkan ke ruang kelas untuk mendorong keterlibatan siswa (Johnson \& McLeod, 2004;Moredich \& Moore, 2007; Ribbens, 2007).

Penelitian telah menunjukkan bahwa siswa yang secara aktif terlibat akan menyerap dan mempertahankan konten lebih baik (Moredich \& Moore; Trotter, 2005). Hal ini juga telah ditunjukkan bahwa penggunaan berbagai media pengajaran/ metode pembelajaran meningkatkan aktivitas belajar bagi siswa dengan gaya belajar yang berbeda (Barell, 2003; Fink, 2003). Pendekatan berpusat pada peserta belajar (Weimer, 2002) dan kreativitas belajar dari pengalaman yang signifikan (Barell, Fink) yang dipuji sebagai alat untuk menciptakan interaksi di dalam kelas.

Clickers adalah suatu system respon siswa. Penggunaan Clickers sebagai metodologi pengajaran telah diteliti oleh Berry (2009) dan menunjjukkan bahwa teknologi Clickers dapat meningkatkan interaksi siswa dan belajar dalam suatu kursus keperawatan pediatrik didaktis. Sementara manfaat lainnya Clickers dapat memberikan umpan balik langsung kepada para siswa mengenai pemahaman materi kuliah. Clickers juga memungkinkan kelompok kecil dalam pertanyaan problem solving.

Penelitian telah mendukung bahwa Clickers menciptakan suasana interaksi diantara siswa yang meningkatkan pemikiran kritis dan kemampuan untuk memanfaatkan pengetahuan tentang keselamatan dalam lingkungan kelas. Siswa datang ke kelas lebih siap karena mereka tahu akan ada kuis, dan Clickers memberi dukungan dalam merangsang diskusi antara siswa tentang tanggapan terhadap kuiz dengan masuk akal (Fitch, 2004; Hatch et al; Moredich \&; Johnson \& McLeod, 2004. Moore; Ribbens, 2007; Skiba \& Barton, 2006; Stein et al.;Trotter). Dengan memberikan umpan balik segera, mempromosikan belajar dari teman sebaya, dan mendorong berbagi pengalaman, Clickers mendukung gaya pembelajaran orang dewasa (Fitch; 
Moredich \& Moore;Ribbens; Roberts, 2005; Stein et al; Trotter).

\section{REVIEW BEBERAPA HASIL PENELITIAN}

Clickers, sebuah teknologi baru, telah digunakan secara aktif melibatkan siswa dalam ceramah dan memberikan umpan balik segera tentang pemahaman mereka terhadap materi kuliah. Siswa yang tidak memahami di identifikasi sehingga materi yang sulit dapat diklarifikasi (Hatch et al, 2005; Howe \& Strauss, 2000; Moredich \& Moore, 2007; Stein et al, 2006; Trotter, 2005). Sistem software Clickers dapat mengumpulkan hasil dan data agregat yang dapat ditayangkan dalam bentuk grafik yang dapat dilihat oleh seluruh partisipan.

Clickers diperkenalkan di semester pertama tahun 2006 pada kelas senior kursus pediatri. Biaya pengadaan Clickers disubsidi oleh hibah Inovasi Teknologi untuk Pengajaran. Enam puluh lima siswa berada di kelompok ini, 40 di situs lokal dan yang lain pada lokasi jauh; lima adalah laki-laki.

Siswa menerima daftar teks yang dibutuhkan (keperawatan anak, keperawatan komunitas, dan teori keluarga). Perbandingan hasil siswa di gunakan nilai semester pertama tahun 2005 secara kohort yang terdiri dari 61 siswa. Siswa-siswa ini telah diberi takehome kuis akan selesai sebelum pertemuan kelas berikutnya dan dikumpulkan pada akhir pertemuan kelas. Pada tahun 2006, pertanyaan kuis dari 2005 telah direvisi ke format pilihan ganda. Setelah pertanyaan yang diajukan dalam slide Power Point, Clickers memungkinkan fakultas untuk menentukan pemahaman siswa dan memperluas diskusi tentang bidang topik. umpan balik segera dan diskusi tentang mengapa jawaban benar atau salah, digalakkan diskusi yang lebih besar dari area topik dan ditingkatkan komunikasi antara siswa dan instruktur.

Metode Evaluasi

Para instruktur kursus mencari jalan baru untuk memfasilitasi keterlibatan siswa dalam kelas. Siswa - siswa yang pandai, tetapi sering merasa bosan dan lalai. Dengan penggunaan Clickers dan kesadaran yang cepat akan bantuan pemahaman konten, adalah memungkinkan dari daerah dimana siswa membutuhkan, sehingga dapat menyesuaikan program sesuai dengan kebutuhan mahasiswa, membatasi waktu yang dihabiskan untuk daerah-daerah yang telah dikuasai siswa dan memperkenalkan topic yang lebih menantang.

Alat survei untuk evaluasi metode ini dikembangkan oleh enam profesor yang terlibat dalam seluruh sistem evaluasi universitas yang menggunakan Clickers dalam kelas. Alat survey telah diadaptasi oleh departemen matematika dan biologi universitas ini, dan alat tersebut telah di share melalui Network for Excellence in Teaching (NET).

Data statistik terdapat perbedaan yang signifikan pada rata-rata skor untuk ujian kedua dan program nilai keseluruhan antara kelas tahun 2005 dan kelas tahun 2006. Skor lebih tinggi di kelas yang menggunakan Clickers. Narasi sambutan dari siswa memberikan dukungan dari pengamatan bahwa Clickers menciptakan setting di mana siswa berinteraksi dengan teman sekelas dalam diskusi dan lebih terlibat ketika menanggapi pertanyaan. Untuk mengatasi masalah tentang biaya pembelian Clickers, universitas telah mengevaluasi sistem remote dan bekerja untuk menurunkan biaya dengan bekerja dengan satu vendor.

Penelitian ini terjadi pada satu pedesaan Midwestern. Program 
keperawatan menawarkan gelar sarjana muda. Oleh karena itu, temuan mungkin tidak berlaku untuk program lain. Meskipun kelompok mahasiswa yang menggunakan Clickers adalah serupa dalam pengukuran, komposisi siswa, dan penerimaan nilai rata-rata, kurikulum dan untuk karakteristik lainnya. Namun demikian, studi eksplorasi menunjukkan bahwa para siswa lebih terlibat di dalam kelas saat menggunakan Clickers, ditinjau dari bahan sebelum sesi kelas, persiapan kuis clicker, dan interaksi mereka selama penyajian pertanyaan clickers mengungkapkan siswa terlibat dalam proses berpikir. Secara keseluruhan, siswa menyatakan sikap positif terhadap penggunaan Clickers di kelas, tetapi melihat beban biaya sebagai atribut negatif. Peneliti akan terus mengevaluasi respon siswa peserta kursus di seluruh universitas yang mulai menggunakan Clickers di dalam kelas. Diasumsikan bahwa beberapa siswa mungkin datang ke kursus dengan pengalaman dipenggunaan Clickers dan mungkin sudah memiliki perangkat remote. Dengan menggunakan lebih banyak Clickers di dalam kelas, diharapkan bahwa biaya teknologi ini akan lebih ringan.

\section{PEMBAHASAN}

Proses untuk mengembangkan suatu kursus menjadi berpusat pada pembelajaran untuk mencapai pembelajaran yang bermakna membutuhkan suatu proses yang dimulai dengan mengidentifikasi 3 komponen design kursus yang meliputi (1) tujuan pembelajaran, (2) kegiatan belajar mengajar, (3) Umpan balik dan penilaian (Fink LD, 2003). Clickers dapat mendukung hal ini. Meedzan, N. \& Fisher, K (2009) juga telah meneliti tentang penggunaan metode Clickers, secara keseluruhan, temuan menunjukkan bahwa siswa merasa puas dengan penggunaan Clickers di dalam kelas dan mendorong instruktur untuk terus menggunakan Clickers untuk kelas di masa depan. Menariknya, siswa tidak menemukan Clickers menjadi faktor motivasi utama untuk menghadiri kelas, tetapi ini bisa dijelaskan oleh kebijakan wajib hadir di sekolah perawat. Ini adalah kewajiban bagi pendidik perawat untuk pindah ke mengadopsi metode pengajaran yang lebih non tradisional. penelitian lebih lanjut diperlukan untuk memvalidasi hasil belajar menyediakan teknologi pendidikan berdasarkan bukti dan teknik untuk generasi berikutnya bagi pendidik dan mahasiswa keperawatan. Hasil dari penelitian ini mencapai hasil positif dari satu teknologi non-tradisional, Clickers sebagai alat yang berguna dalam menyelesaikan tugas ini.

Dalam melakukan kursus tentunya akan banyak media yang digunakan dan hal-hal yang harus dipertimbangkan dalam memilih media adalah: (a) Ketepatan dengan tujuan pembelajaran; (b) Dukungan terhadap isi pembelajaran; (c) Kemudahan memperoleh media; (d) Keterampilan pengajar dalam menggunakannya; (e) Ketersediaan waktu menggunakannya; (f) Sesuai dengan taraf berfikir siswa

Pada pelaksanaan kursus tentu akan banyak spesifikasi keilmuan dan ketrampilan yang akan ditransfer kepada peserta didik. Sehingga tidak semua dapat diselenggarakan dengan satu media saja atau dengan Clickers saja seperti yang dikemukakan oleh Fink LD (tahun 2003) bahwa pembelajaran yang bermakna terbagi dalam 4 kategori yaitu Fondational Knowledge, application, Integrasi dan dimensi manusia, sehingga dalam melakukan kegiatan belajar mengajar 
harus melihat tujuannya. Bila untuk tujuan transfer ketrampilan maka media ini akan kurang optimal karena profesi perawat melakukan suatu proses asuhan kepada pasien yang dalam hal ini merupakan manusia dengan karakter yang unik. Sebagaimana penelitian yang dilakukan oleh Jennifer et al (2010) yang melakukan penelitian pembelajaran secara online versus simulasi pada bahasan prinsip prinsip ventilasi mekanik untuk praktek keperawatan lanjut (Advance Practice Nursing) dan didapatkan hasil kedua kelompok mengalami perbaikan yang signifikan dalam skor pengetahuan dari pretest ke posttest, namun skor pengetahuan tidak signifikan berbeda pada posttest antara kelompok. Kepuasan Siswa dengan metode belajar simulasi secara signifikan lebih tinggi dalam kelompok. Siswa kelompok simulasi dianggap lebih memahami materi dan kemampuan mereka dapat terhubung dengan praktik berbasis bukti kepada pasien yang membutuhkan ventilasi mekanis.

Faktor kemudahan memperoleh media masih belum menjangkau untuk wilayah Indonesia, clicker telah diadopsi oleh ribuan fakultas (Boston, California, Colorado, New Mexico dan lain-lain) dan digunakan oleh lebih dari 1 juta siswa dalam waktu kurang dari dua tahun. Pelanggan Clickers memberikan umpan balik, mereka konsisten dengan clicker, bahkan clicker sangat dapat diandalkan dengan tingkat kerusakan 0,0007\%. Pada keterampilan pengajar dalam menggunakannya dan ketersediaan waktu menggunakannya tidak menjadi masalah karena kemudahan teknnologinya

Mengingat masing masing siswa mempunyai gaya belajar yang berbeda beda maka akan dibutuhkan banyak metode untuk proses pembelajaran. Clickers dapat mendukung dalam konteks belajar, sedangkan dalam aspek asupan belajar tidak semua tipe dapat didukung Clickers. Clickers dapat mendukung visual, dan auditory, namun tidak pada kinesthetic.

\section{SIMPULAN}

1. Clickers membantu dalam pemahaman konten dan membawa keterlibatan siswa yang lebih besar selama kuliah.

2. Komentar Kepuasan juga mendukung penggunaan Clickers sebagai alat untuk melibatkan para siswa dan meningkatkan hasil belajar.

3. Clickers memudahkan proses pengajaran, memudahkan pengajar dalam penilaian dan pelaporan hasil belajar siswa.

4. Penggadaan Clickers membutuhkan biaya, namun bisa dengan mengusahakan biaya Hibah

5. Clickers merupakan pendukung dalam kegiatan belajar mengajar, perlu dikembangkan untuk beranjak pada system yang lebih maju tetapi bukan merupakan media yang utama. 
Pustaka

Jurnal Utama:

Berry Janice, (2009),Technologi Support in Nursing Education:Clickers in the Classroom ; Nursing Education Perspectives, 2009 Sep-Oct; 30 (5): 295-8 (journal article - research, tables/charts) ISSN: 1536-5026 PMID: 19824239 CINAHL AN: 2010428398

Jurnal dan buku pendukung : Barell, J. (2003). Developing more curious minds.Alexandria,VA: Association for Supervision and Curriculum Development.

Corbridge J Susan,Tiffen Jennifer,et all (2010) Online Learning versus Simulation for Teaching Principles of Mechanical Ventilation to Nurse Practitioner Students, International Journal of Nursing Education Scholarship,Volume 7, Issue 12010 Article 12

Fink, L. D. (2003). Creating significant learning experiences:An integrated approach to designing college courses. San Francisco: Jossey-Bass.

Fitch, J. (2004). Student feedback in the college classroom:A technology solution. Education Technology Research and Development, 52(1),71-81.

Gunarya Arlina, (2006), 'Perilaku Belajar" , Modul TOT Basic Study Skills, untuk Calon Pelatih Basic Study Skill bagi Mahasiswa Universitas Hasanuddin.
Hatch, J., Jensen, M., \& Moore, R. (2005). Manna from heaven or "Clickers" from hell: Experiences with an electronic response system. Journal of College Science Teaching, 34(7), 36-42.

Howe, N., \& Strauss,W. (2000) Millennials rising:The next great generation. New york:Vintage.

Johnson, D., \& McLeod, S. (2004). Get answers:Using student response system to see students' thinking. Learning and Leading with Technology,32(4), 18-23.

Moredich, C., \& Moore, E. (2007). Engaging students through the use of classroom response systems. Nurse Educator, 32(3), 113-116.

LD Fink (2003), Creating Significant Learning Experiences: An Integrated Approach to Designing College Courses. San Francisco, CA, Josey-Bass, Vol 24, No 3, Fall 2010 Journal of Physical Therapy Education

Meedzan, N. \& Fisher, K. (2009). Clickers in Nursing Education: An Active Learning tool in the Classroom. Online Journal of Nursing Informatics (OJNI), 13, ( 2 ). Available http://ojni.org/13\%5f2/Meedzan\%5fFisher .pdf

Richardson, K., \& Trudeau, K. (2003). A case for problem-based collaborative learning in the nursing classroom. Nurse Educator, 28(2), 83-88. 